Contents lists available at Journal Redwhitepress
Journal of Educational and Learning Studies
ISSN: 2655-2760 (Print) ISSN: 2655-2779 (Electronic)
Journal homepage: http://journal.redwhitepress.com/index.php/jles

\title{
Assertive Behavior of Minangkabau and Batak Implications in Development Services Social Capability
}

\author{
Nurul Fajri ${ }^{1}$, Herman Nirwana $^{2}$, Alizamar $^{3}$ \\ ${ }^{123}$ Universitas Negeri Padang
}

\begin{tabular}{|c|c|}
\hline Article Info & ABSTRACT \\
\hline Article history: & \multirow{7}{*}{$\begin{array}{l}\text { One of the roles of BK Counselors in schools is to assist students to become } \\
\text { independent and optimally developed in various fields such as social } \\
\text { interaction. It is greatly influenced by assertive behavior. The research } \\
\text { determines the assertive behavior in men and women using Minangkabau and } \\
\text { Batak cultures as a case study. The sample used in this study was } 413 \text { which } \\
\text { comprises of } 191 \text { Minangkabau students and } 222 \text { Batak students selected by the } \\
\text { cluster random sampling technique. Therefore, the instrument used in this } \\
\text { study is the scale of assertive behavior with a reliability level of } 0.930 \text {. The } \\
\text { findings of the research show a medium attribute with significant differences in } \\
\text { both cultures. Therefore, it is recommended that counselors make use of } \\
\text { structuring techniques, while explaining the principle of confidentiality and } \\
\text { openness to students. }\end{array}$} \\
\hline Received Nov $30^{\text {th }}, 2018$ & \\
\hline Revised Mar 28 $8^{\text {th }}, 2019$ & \\
\hline Accepted Apr 03 ${ }^{\text {rd }}, 2019$ & \\
\hline Keyword: & \\
\hline Assertive Behavior & \\
\hline Minangkabau and Batak Culture & \\
\hline
\end{tabular}

\section{Corresponding Author:}

Nurul Fajri,

Universitas Negeri Padang

Email: nurulfajriab21@gmail.com

\section{Introduction}

One essential quality that all adolescents must possess is social-emotional interaction, which aims at developing assertive skills (Santrock, 2003). This behavior needs to be developed in adolescents, because they are more vulnerable to negative environmental influences (Anindyajati\&Karima, 2004; Alizamar, 2013). Its existence tends to make teenagers remain neutral in their groups (Tika\&Suryanto, 2015; Sriyanto, Abdulkarim, Zainul, \&Maryani, 2014). Therefore, the existence of self-disclosure in teenagers can enhance interpersonal relations (Nirwana, 2012).

Assertive behavior is influenced by many things such as culture, which indirectly affects an individual's demeanor (Watie, 2011). Furthermore, cultural values cannot be separated an adolescent's assertive behavior (Lee \&Ciftci, 2014). Some of the studies previously described illustrate that ethnic and cultural norms influence the willingness of individuals to ask questions, express concern, or be self-confident (Alston, 2003; Taras, Rowney, \& Steel, 2013). Therefore differences in assertive behavior between cultures are influenced by the values adopted by each which also affect the role of men and women. According to a research conducted by Rina \& Ivan, (2016) individuals with Minangkabau cultural backgrounds adhere to extreme matrilineal family system and display their emotions while those with Batak culture are quite expressive with a family patrilineal extreme system (Nirwana, 2003).

The Batak community is a family which draws the lineage of the male ancestors (Gultom, 2017), while the Minangkabau is a culture with thick nuances of emancipation and feminist teachings (Ariani, 2015). Education is a medium used to transmit culture, values, and behaviors. A nation will lose its character and identity if it separates cultural values in its education, both theoretically and practically. 
Guidance and counseling are part of the educational structure, therefore, its application in schools must also consider the prevailing cultural values. Pedersen (Masturi, 2017) stated that it is the fourth cross-cultural approach after a psychodynamic, behavioral, and humanistic approach. This is owing to the humanitarian relationship between the counselor and client with respective characteristics, personalities, values, and morals (Supriatna, 2009).

\section{Method}

This research uses a quantitative approach with a comparative descriptive study, and aims to compare the assertive behaviorial data of Minangkabau and Batak students. The population comprises of 1673 students of SMA Negeri 1 Batusangkar Balige at West and North Sumatra. 191 students were from Minangkabau cultural backgrounds and 222 from Batak. The Study participants were randomly taken from three grade levels using the cluster random sampling technique, with data reliability carried out by considering the Cronbach Alpha value. The assertive behavior instrument is 0.930 , however if it is $\geq 0.80$ the value is reliable. To find out the difference between independent and dependent variables, data was analyzed using Analysis Of Variants (ANOVA) and Statistical Product and Service Solution (SPSS) program version 20.0.

\section{Results and Discussions}

\section{Results}

The testing of the behavior hypothesis of students in terms of background using ANOVA can be seen in the following Table:

Table 1 The difference in Score of Assertive Behavior of Students Judging from Background of Minangkabau and Batak

\begin{tabular}{|c|c|c|c|c|c|c|c|c|}
\hline Variable & $\begin{array}{l}\text { Culture } \\
\text { Cultural } \\
\end{array}$ & $\mathbf{N}$ & Mean & Dk & MS & $\mathrm{F}$ & Sig. & Ket \\
\hline \multirow{2}{*}{$\begin{array}{l}\text { Assertive } \\
\text { Behavior }\end{array}$} & Minangkabau & 191 & 115 & \multirow[t]{2}{*}{1} & \multirow[t]{2}{*}{1918.47} & \multirow[t]{2}{*}{17.48} & \multirow[t]{2}{*}{0.00} & significantl \\
\hline & Batak & 222 & 111 & & & & & $\mathrm{y}$ \\
\hline
\end{tabular}

Based on the analysis in the table, it can be seen that assertive behavior variable, and students cultural backgrounds, are $p=0.00$. In accordance with hypothesis criteria, if the sign is smaller than 0.05 , then there is a significant difference in assertive behavior of students from Minangkabau and Batak backgrounds and $\mathrm{H} 1$ is accepted. In other words, students with Minangkabau backgrounds are more assertive, than those from Batak.

\section{Discussion}

Based on the hypothesis testing using the ANOVA, and with $p$ value of 0.00 , if the sign is smaller than 0.05 , then there is a significant. Minangkabau is one of the cultures found in Indonesia which uses a combination of thoughts and feelings to determine (Zainuddin, 2010). feelings (Suciati, 2016). Therefore, teenagers of this community make proper consideration before expressing their feelings. This is in contrast with the background of Batak culture, which is based on research. Anggraini (2011), stated that it is common for adolescents of this community to communicate using their native language. High tones, fast speech, and sharp eyes contacts often make people regard them as cruel and rude. According to Monika (2012), the Batak tribe uses the dalihannatolu term to explain individual's social behavior. It originally means a three-legged stove which cannot be used if a part is damaged. The connection with emotional expression is in the form of behavior, words or facial expressions that are being felt. Galassi (1977) stated that in assertive behavior, several components must be considered including eye contact, body language, fluency, tone, module and volume, placement, facial expression, cues, listening, thinking, content and culture. Therefore, it can be concluded that people who are able to express their feelings may not be able to behave assertively. 


\section{Conclusions}

In conclusion, the number of students with Minangkabau cultural backgrounds is greater than those with Batak significantly.

Furthermore, school counselors are required to understand the values and behavior of student from both Minangkabau and Batak. Through the provision of services such as adat bersandi syara', syara' bersandi kitabullah and dalihannatolu, students would be encouraged to be independent.

\section{References}

Alizamar. (2013). Upaya Guru Bimbingan dan Konseling dalam Mencegah Perilaku Bullying di SMA Negeri Se Kota Padang. Jurnal Ilmiah Konseling, 2(3), 21-25.

Alston, M. B. (2003), "Profile of Uphill Battle", Journal of Dairy Science,. 8, 347-351

Ariani, I. (2015). Budaya Matrilineal di Minangkabau (Relevansinya Bagi Pengembangan Hak-Hak Perempuan di Indonesia). Jurnal Filsafat, 25(1):33-55.

Gultom, E. R. (2017). Development of Women Position in the Patrilineal Inheritance of Indonesian Society. Jurnal Dinamika Hukum, 8(2), 6-7.

Galassi, M. D., \& Galassi, J. P. (1977). Assert Yoir Self, How To Be Your Own Person. New York: Human Sciences Press

Masturi. (2017).Counselor Encapsulation: Sebuah Tantangan Dalam Pelayanan Konseling Lintas Budaya. Jurnal Konseling Gusjigang, 1(2), 1-14.

Monika, E. (2012). Budaya Patriarki Batak Toba dan Perilaku Politik Perempuan. umatra Utara: USU press.

Nirwana, H. (2003). Perbedaan Tingkat Aspirasi dan Persepsi tentang Belajar Matematika antara Siswa B erlatar Budaya Minangkabau dan Batak. Jurnalllmu Pendidikan, jilid 12, 1-13.

Nirwana, H. (2012). Pengungkapan Diri Siswa Sekolah Menengah dan Implikasinya Bagi Konseling. Jurnal Ilmu Pendidikan, 18(1), 1-7.

Rina. S., \& Ivan, M. A. (2016). Perbedaan Ekspresi Emosi pada Orang Batak,Jurnal Psikologi, 12(12), 99108.

Santrock, J. W. (2003). Adolescence: PerkembanganRemaja.(EdisiKeenam) Jakarta: Erlangga

Supriatna, M. (2009). Bimbingan dan Konseling Lintas Budaya. Materi PLPG PPB, FIP, UPI

Suciati, R.,\& Ivan, M., A. (2016). Perbedaan Ekspresi Emosi pada Orang Batak,Jurnal Psikologi, 12(12), 99108.

Sriyanto, Abdulkarim, A., Zainul, A., \& Maryani, E. (2014). Perilaku Asertif dan Kecenderungan Kenakalan Remaja Berdasarkan Pola Asuh dan Peran Media Massa. Jurnal Psikologi, 41(1), 74-88.

Tika, M., \& Suryanto. (2015). Self Disclosure, Perilaku Asertif dan Kecenderungan Terhindar dari Tindakan Bullying. Jurnal Psikologi Indonesia, 4(2), 208-215.

Taras, V., Rowney, J., \& Steel, P. (2013), "Work-Related Acculturation: Change In Individual WorkRelated Cultural Values Following Immigration", The International Journal of Human Resource Management, 24 (1), 130-151

Watie, E. D. S. (2011). Komunikasi dan Media Sosial (Communications and Social Media ). The Messenger, $3(1), 69-75$. 
Lee, J. Y., \& Ciftci, A. (2014). Asian International Students' Socio-Cultural Adaptation: Influence of Multicultural Personality, Assertiveness, Academic Self-Efficacy, and Social Support. International Journal of Intercultural Relations, 38(1), 97-105.

Zainuddin, M. 2010. Pelestarian Eksistensi Dinamis Adat Minangkabau. Yogyakarta: Penerbit Ombak. 